\title{
Characteristics of Postoperative Pain After VATS and Pain-Related Factors: The Experience in National Cancer Center of China [Corrigendum]
}

\begin{abstract}
Tong Y, Wei $\mathrm{P}$, Wang $\mathrm{S}$, et al. $J$ Pain Res. 2020;13:1861-1867.

The authors previously advised the affiliation on page 1861 was incorrect. A corrigendum was published September 21, 2020 , however the authors have requested additional changes to the affiliation.
\end{abstract}

The correct affiliation should read "Department of Thoracic Surgery, National Cancer Center/National Clinical Research Center for Cancer/Cancer Hospital, Chinese Academy of Medical Sciences and Peking Union Medical College, Beijing 100021, People's Republic of China".

The authors apologize for this error.

\section{Publish your work in this journal}

The Journal of Pain Research is an international, peer reviewed, open access, online journal that welcomes laboratory and clinical findings in the fields of pain research and the prevention and management of pain. Original research, reviews, symposium reports, hypothesis formation and commentaries are all considered for publication. The manuscript management system is completely online and includes a very quick and fair peer-review system, which is all easy to use. Visit http:// www.dovepress.com/testimonials.php to read real quotes from published authors. 